$\xi=$

\title{
Elemental composition of wild colisa lalia in relation to body size and condition factor from Pakistan
}

\author{
Summera Fatima *, Muhammad Naeem \\ Institute of Pure and Applied Biology, Bahauddin Zakariya University, Multan 60800, Pakistan \\ *Corresponding author E-mail: summera_fatima@yahoo.com
}

\begin{abstract}
Twenty three samples of wild fish Colisa lalia were collected from Nala Daik, a stream in Sialkot. The concentration of Cadmium (Cd), Cobalt (Co), Iron (Fe), Manganese (Mn) and Nickel (Ni) in the whole fish were determined by Flame atomic absorption spectrophotometer to estimate the water contamination and health risk of human consumption in Sialkot region which is a popular industrial area. The detected cobalt in twenty two samples and nickel in eight samples exceeds the permitted limits for fish set by IAEA-407 (Wyse et al. 2003). While the concentration of Cadmium, Iron and Manganese in all samples were below permitted level set by European and other International Organizations. The concentration of $\mathrm{Cd}, \mathrm{Co}, \mathrm{Fe}, \mathrm{Mn}$ and $\mathrm{Ni}$ was ranging from $0.20-1.71,0.84-55.38,82.82-137.63,1.61-$ $22.73,2.23-5.98$ having mean value as $0.67,39.31,139.09,13.26$ and 0.56 (ug/g wet weight) respectively. Regressions analysis was performed for both size and condition factor with metal concentrations. As far as correlation with total length and weight was concerned, a decreasing trend was shown by $\mathrm{Cd}$ and $\mathrm{Ni}$ while $\mathrm{Co}, \mathrm{Fe}$ and $\mathrm{Mn}$ showed an increasing trend and these correlations were found significant for all these elements. No effect of condition factor was observed in the study on Colisa lalia. Inter-elemental regression showed significant correlations among metals.
\end{abstract}

Keywords: Elemental composition; Sialkot region; Spectrophotometer; body size; condition factor.

\section{Introduction}

Fish provide protein for the increasing population, especially in the developing countries of Africa, Asia and South America and in such countries increased fish production can compensate the dietary protein shortage (Nnaji et al. 2009, Zhu et al. 2015). For maintenance of healthy life, Omega-3 fatty acid and important vitamins are provided by fish( Ozuni et al. 2010), so it is a part of human diet because some biological experiments have confirmed that it is nutritionally equivalent to meat, milk, eggs (FAO, 1995). In addition, human functioning becomes better by eating fish. Oil of fish is also healthful as it contains many healthy acids (Rafflenbeul, 2001). But many research literatures also suggest that fish consumption may be dangerous because of the presence of environmental pollutants. While eating fish can improve health and increase healthy life, mercury, pesticides, and other pollutants associated with chronic diseases and cancer appear to be present in almost all fish (Linkov et al. 2009). Heavy metals are introduced into the water, through sewage of homes and waste of industries and have harmful effects both on the environment and ecology (Abu-Darwish et al., 2011, Waqar et al. 2013). The water of rivers become contaminated by many damaging metals, discharging because of human activities, as waste of industries and agriculture, sewage form homes, seepage of groundwater has damaging effects on the equilibrium of the receiving environment and wide range of water biota (Sobha et al. 2007, Taweel et al. 2013, Kousar \& Javed, 2014 ). In urban areas, running rivers have been polluted due to addition of sewage from home, excretory wastes and pollutants from industries into water causing high rate of toxicity of metals in the water of river (Venugopal et al. 2009, Sekabira et al. 2010). In aquatic environment, pollution of heavy metals is in- creasing at drastic point and has become a major problem throughout the world. Because break down of heavy metals cannot be done, these are accumulated, become part of body or enter in water, sediment and animals in water and so, result in pollution of heavy metal in water medium (Malik et al. 2010, Yap et al. 2015). That's why; through the food chain heavy metals can be bio accumulated and increased in amount and resultantly become part of human body becoming risk for health (Agah et al. 2009). In aquatic organism, metal bioaccumulation is not related simply to the surrounding concentration but is also affected by complex geochemical and biological factors (Zhang \& Wang, 2007, Kousar \& Javed, 2014). Both field and research laboratory experiments show that in fish addition of heavy elements is mainly because of metals concentration in surrounding water medium and duration of exposure, although in metal accumulation these aspects such as level of salt in water, $\mathrm{pH}$, hardness of water medium and temperature, ecological demands, weight and age, life cycle of development, season of capture and diet of fish also has an important part (Canli \& Atli, 2003). Similarly, the speed of intake, storage capability and removal have also role in accumulation of metals in fish tissue (Longston, 1990). Different metal ions get magnified biologically with their growth, when get entry in their different tissues from the surrounding water. Fish are considered as the most indicative factors for water pollution (Cid et al. 2001, Rashed, 2001, Papagiannis et al. 2004, Ashraf, 2005, Lavilla et al. 2008, Kousar \& Javed, 2014). Age and body size are two important biological aspects among the many factors affecting metal bioaccumulation (Phillips, 1980, Newman \& Doubet, 1989, Zhang \& Wang, 2007). Metal toxicity also depend on fish length and weight (Kroupa \& Hartvich, 1990, Falandysz, 1994, Kostecki, 2000). Depending on size, many authors have seen variations in metal toxicity of fish 
(Luczynska \& Tonska, 2006, Promya \& Chitmanat, 2011). Area of research, Sialkot is famous for industrial plants like leather industry, surgical parts, medicines and drug industry, juice factory, textile and steel mills. As this city is more populated so facing problem of pollution in water and air. Quality of water is affected by wastes of domestic usage, industries and agriculture wastes. So water of streams, ponds and agricultural area is becoming polluted with passage of time (Sialkot Water Supply, Sewerage and Drainage Strategy and Action Plan, 2010). The present study investigate the elemental composition in wild Dwarf gourami, Colisa lalia indicating water pollution, and relating the concentration of metals with respect to fish size and condition factor.

\section{Materials and methods}

Collecting Samples Twenty three samples of wild fish Colisa lalia were collected from Sialkot. Collected fish were transported to the Fisheries Laboratory, Institute of Pure and Applied Biology, Bahauddin Zakariya University, Multan in plastic containers. The fresh fish were washed immediately to free it from adhering blood and slime, on arrival of laboratory. Total length (TL) of collected fish samples were measured by using wooden measuring tray and weighed (W, wet weight) on an electronic balance (MP-3000 Chyo, Japan).

\subsection{Preparing of sample solutions and analysis}

The dried Samples were converted into ash by keeping in furnace at 500 o $\mathrm{C}$ for many hours. Then these ashed samples were dissolved in $1 \% \mathrm{HNO}$, filtration was done depending on requirement and $25 \mathrm{ml}$ diluted solutions were prepared by dissolving in deionized water (having $1 \% \mathrm{HNO} 3$ ). These solutions were kept in bottles by writing fish name for the analysis of metals. The analysis of these sample were made with iCE-3000 atomic absorption spectrophotometer (Thermo fisher, UK) to determine the concentration of $\mathrm{Cd}, \mathrm{Co}, \mathrm{Fe}, \mathrm{Mn}$ and $\mathrm{Ni}$ at Food Science laboratory, University college of Agriculture Bahauddin Zakariya University, Multan . After every ten samples calibration of the instrument was repeated during operation.

\subsection{Statistical measurement}

Microsoft Excel 10.0 software (Copyright @ Microsoft Corporation) was used for all data tables and for all the statistical analyses. Statistical measurement for each trait was expressed as Mean \pm Standard Error. It was purpose of the current research to show the relationship between fish length and concentrations of $\mathrm{Cd}, \mathrm{Co}, \mathrm{Fe}$, $\mathrm{Mn}$ and $\mathrm{Ni}$ in the fish and so the correlation coefficients were observed between element concentration and fish size (length and weight). The statistical analyses regression analysis, computation of correlation coefficients and standard error the student's t-test were applied. For analyzing the effect of condition on the element load of fish, Fulton's Condition Factor indicate individual condition factor of fish. The variations of element concentration with length and weight of samples were determined by using the ANOVA technique. Multiple regression analysis is done to determine the relationship of elements with body weight, total length as well as condition factor.

\section{Results}

Elemental composition of twenty three samples of wild Dwarf gourami Colisa lalia was analyzed. The values of cadmium, cobalt, iron, manganese and nickel in Colisa lalia are shown in (Table-1). Accumulation of studied elements followed this descending order: $\mathrm{Fe}>\mathrm{Co}>\mathrm{Ni}>\mathrm{Mn}>\mathrm{Cd}$.
Table 1: Grand Mean and Standard Error Values of Metal Concentrations in Carcasses of Colisa Lalia (Whole Fish), $\mathrm{N}=23$

\begin{tabular}{lll} 
Elements & $\begin{array}{l}\text { Concentration in wet weight } \\
(\mu \mathrm{g} / \mathrm{g}) \\
\text { Mean } \pm \mathrm{SE}\end{array}$ & $\begin{array}{l}\text { Concentration in dry weight } \\
(\mu \mathrm{g} / \mathrm{g}) \\
\text { Mean } \pm \mathrm{SE}\end{array}$ \\
\hline $\mathrm{Cd}$ & $0.67 \pm 0.100$ & $2.45 \pm 0.3688$ \\
$\mathrm{Co}$ & $39.31 \pm 5.7333$ & $142.32 \pm 20.6970$ \\
$\mathrm{Fe}$ & $139.09 \pm 28.4578$ & $489.38 \pm 92.2079$ \\
$\mathrm{Mn}$ & $13.26 \pm 1.6578$ & $48.76 \pm 6.6287$ \\
$\mathrm{Ni}$ & $0.56 \pm 0.0753$ & $89.03 \pm 13.131$ \\
\hline
\end{tabular}

\subsection{Relationship of body weight and total length with metal concentrations}

The values of $\mathrm{Cd}, \mathrm{Fe}, \mathrm{Mn}$ and $\mathrm{Ni}$ were observed highly significant with the fish weight and total length. Co showed significant relationship $(\mathrm{P}<0.01)$ with body weight and total length. In samples of Colisa lalia, $\mathrm{Ni}$ and $\mathrm{Cd}$ concentrations showed inverse relationship with weight and length while $\mathrm{Mn}, \mathrm{Fe}$ and Co showed a significant increase or remain constant in concentrations with an increase in total weight and length (Table- $2 \& 3$ ).

Table 2: Regression Parameters of Log Wet Body Weight (G) Versus Log Total Body Burden Element $(\mu \mathrm{g})$ for Wild Colisa Lalia $(\mathrm{N}=23)$ [Log Body Burden Element $(\mathrm{Mg})=\mathrm{A}+\mathrm{B} \log$ Wet Body Weigt $(\mathrm{G})]$

\begin{tabular}{|c|c|c|c|c|c|c|}
\hline $\begin{array}{l}\text { Wet body } \\
\text { weight }(\mathrm{g})\end{array}$ & Elements & $r$ & a & $\mathrm{b}$ & $\begin{array}{l}\text { S.E } \\
\text { (b) }\end{array}$ & $\begin{array}{l}\text { value } \\
(\mathrm{b}=1)\end{array}$ \\
\hline \multirow{5}{*}{0.59 to 3.56} & $\mathrm{Cd}$ & $0.699 * * *$ & $\overline{0} .256$ & 0.960 & 0.214 & $4.480 * * *$ \\
\hline & $\mathrm{Co}$ & $0.599 * *$ & 1.430 & 1.169 & 0.340 & $3.431^{* *}$ \\
\hline & $\mathrm{Fe}$ & $0.783^{* * * *}$ & 1.970 & 1.370 & 0.237 & $5.769 * * *$ \\
\hline & $\mathrm{Mn}$ & $0.775^{* * *}$ & 0.920 & 1.413 & 0.251 & $5.624 * * *$ \\
\hline & $\mathrm{Ni}$ & $0.779 * * *$ & 1.307 & 1.072 & 0.188 & $5.702 * * *$ \\
\hline
\end{tabular}

$\mathrm{a}=$ Intercept $; \mathrm{b}=$ Slope; S.E $=$ Standard Error; $\mathrm{r}=$ Correlation Coefficient; $* * *=\mathrm{P}<0.001 ;$ n.s. $=>0.05$,

Table 3: Regression Parameters of Log Total Length (TL, Cm) Versus Log Total Body Burden Element $(\mu \mathrm{g})$ for Wild Colisa Lalia $(\mathrm{N}=23)[\mathrm{Log}$ Body Burden Element $(\mathrm{Mg})=\mathrm{A}+\mathrm{B}$ Log Wet Body Weigt $(\mathrm{G})]$

\begin{tabular}{|c|c|c|c|c|c|c|}
\hline $\begin{array}{l}\text { Total } \\
\text { length }(\mathrm{cm})\end{array}$ & Elements & $\mathrm{r}$ & $\mathrm{a}$ & b & $\begin{array}{l}\text { S.E } \\
\text { (b) }\end{array}$ & $\begin{array}{l}\text { t value } \\
(\mathrm{b}=3)\end{array}$ \\
\hline \multirow{5}{*}{3.1 to 5.7} & $\mathrm{Cd}$ & $0.704 * * *$ & $\overline{1.834}$ & 2.807 & 0.618 & $4.54 * * *$ \\
\hline & Co & $0.619 * *$ & $-\overline{0.543}$ & 3.508 & 0.970 & $3.615^{* * *}$ \\
\hline & $\mathrm{Fe}$ & $0.779 * * *$ & $-\overline{0.252}$ & 3.960 & 0.694 & $5.694 * * *$ \\
\hline & $\mathrm{Mn}$ & $0.770 * * *$ & $-\overline{1.368}$ & 4.077 & 0.737 & $5.531 * * *$ \\
\hline & $\mathrm{Ni}$ & $0.779 * * *$ & - 0.441 & 3.115 & 0.546 & $5.702 * * *$ \\
\hline
\end{tabular}

$\mathrm{a}=$ Intercept $; \mathrm{b}=$ Slope $; \mathrm{S} . \mathrm{E}=$ Standard Error $\mathrm{r}=$ Correlation Coefficient $* * *=\mathrm{P}<0.001 ;$ n.s. $=>0.05$

\subsection{Relationship between elemental concentrations and condition factor}

Regression analysis among metal concentrations (wet body weight, $\mu$ gg-1) and condition factor of Colisa lalia showed insignificant relationship with increasing condition factor (Table-4).

Table 4: Regression Parameters of Condition Factor Versus Metal Concentration (Wet Weight, $\mu \mathrm{gg}^{-1}$ ) in Wet Body Weight for Wild Colisa Lalia $(\mathrm{N}=23)$ [Body Burden Element $(\mathrm{Mg})=\mathrm{A}+\mathrm{B}$ Condition Factor]

\begin{tabular}{lllllll}
\hline $\begin{array}{l}\text { Condition } \\
\text { factor }\end{array}$ & Elements & $\mathrm{r}$ & $\mathrm{a}$ & $\mathrm{b}$ & $\mathrm{S} . \mathrm{E}(\mathrm{b})$ & $\begin{array}{l}\mathrm{t} \text { value } \\
(\mathrm{b}=0)\end{array}$ \\
\hline & $\mathrm{Cd}$ & $\begin{array}{l}0.078 \\
\mathrm{~ns}\end{array}$ & 1.011 & -0.164 & 0.457 & -0.360 \\
& $\mathrm{Co}$ & $\begin{array}{l}0.191 \\
\mathrm{~ns}\end{array}$ & 86.966 & -23.101 & 25.767 & -0.896 \\
1.73 to & $\mathrm{Fe}$ & $\begin{array}{l}0.018 \\
\mathrm{~ns}\end{array}$ & 161.994 & -11.103 & 130.300 & -0.085 \\
2.78 & $\mathrm{Mn}$ & $\begin{array}{l}0.255 \\
\mathrm{~ns}\end{array}$ & 31.630 & -8.903 & 7.339 & -1.213 \\
& $\mathrm{Ni}$ & $\begin{array}{l}0.017 \\
\mathrm{~ns}\end{array}$ & 0.506 & 0.028 & 0.344 & 0.082 \\
\hline
\end{tabular}

$\mathrm{a}=$ Intercept $\mathrm{b}=$ Slope; S.E $=$ Standard Error; $\mathrm{r}=$ Correlation Coefficient; $* * *=\mathrm{P}<0.001 ;$ n.s. $=>0.05$ 


\subsection{Multiple regression analysis (MRA)}

For calculating regression analysis between two factors like length and weight, insignificant relationship was found ( $p>0.05)$ for $\mathrm{Cd}$ Co. $\mathrm{Fe}, \mathrm{Mn}$ but significantly high relationship was found $(\mathrm{P}<0.001)$ for Ni values in observed fish (Table-5). Multicollinearity was also observed by variance-inflation factors VIF having value less than ten.

Table 5: Multiple Regressions Analysis of Wet Body Weight (W, G.) and Total Length (TL, Cm) with Metal Concentration (Wet Body Weight, Mgg-1) for Colisa Lalia ( $\mathrm{N}=23$ )

\begin{tabular}{|c|c|c|c|c|c|c|}
\hline Relationship & $\mathrm{r}$ & $\mathrm{a}$ & b1 \pm S.E & $\mathrm{b} 2 \pm$ S.E & $\mathrm{r} 2$ & VIF \\
\hline $\begin{array}{l}\mathrm{Cd}=\mathrm{a}+\mathrm{b} 1 \mathrm{TL}+ \\
\mathrm{b} 2 \mathrm{~W}\end{array}$ & $\begin{array}{l}0.093^{\mathrm{n}} \\
\mathrm{s}\end{array}$ & $\begin{array}{l}1.48 \\
9\end{array}$ & $\begin{array}{l}0.267 \pm 0.6 \\
44\end{array}$ & $\begin{array}{l}0.304 \pm 0 . \\
723\end{array}$ & $\begin{array}{l}0.0 \\
08\end{array}$ & $\begin{array}{l}1.0 \\
08\end{array}$ \\
\hline $\begin{array}{l}\mathrm{Co}=\mathrm{a}+\mathrm{b} 1 \mathrm{TL}+ \\
\mathrm{b} 2 \mathrm{~W}\end{array}$ & $\begin{array}{l}0.124^{\mathrm{n}} \\
\mathrm{s}\end{array}$ & $\begin{array}{l}- \\
19.5 \\
0\end{array}$ & $\begin{array}{l}- \\
17.36 \pm 36 \\
69\end{array}$ & $\begin{array}{l}21.20 \pm 4 \\
1.22\end{array}$ & $\begin{array}{l}0.0 \\
15\end{array}$ & $\begin{array}{l}1.0 \\
15\end{array}$ \\
\hline $\begin{array}{l}\mathrm{Fe}=\mathrm{a}+\mathrm{b} 1 \mathrm{TL}+ \\
\mathrm{b} 2 \mathrm{~W}\end{array}$ & $0.305^{\mathrm{n}}$ & $\begin{array}{l}349 . \\
03\end{array}$ & $\begin{array}{l}123.27 \pm 17 \\
4.81\end{array}$ & $\begin{array}{l}- \\
99.24 \pm 1 \\
96.3\end{array}$ & $\begin{array}{l}0.0 \\
93\end{array}$ & $\begin{array}{l}1.1 \\
02\end{array}$ \\
\hline $\begin{array}{l}\mathrm{Mn}=\mathrm{a}+\mathrm{b} 1 \mathrm{TL} \\
+\mathrm{b} 2 \mathrm{~W}\end{array}$ & $0.165^{\mathrm{n}}$ & $\overline{0} .92$ & $\begin{array}{l}- \\
4.10 \pm 10.5 \\
4\end{array}$ & $\begin{array}{l}4.70 \pm 11 \\
85\end{array}$ & $\begin{array}{l}0.0 \\
27\end{array}$ & $\begin{array}{l}1.0 \\
27\end{array}$ \\
\hline $\begin{array}{l}\mathrm{Ni}=\mathrm{a}+\mathrm{b} 1 \mathrm{TL}+ \\
\mathrm{b} 2 \mathrm{~W}\end{array}$ & $\begin{array}{l}0.880 * \\
* *\end{array}$ & 2.43 & $0.18 \pm 0.23$ & $\begin{array}{l}- \\
0.53 \pm 0.2 \\
5\end{array}$ & $\begin{array}{l}0.7 \\
75\end{array}$ & $\begin{array}{l}4.4 \\
44\end{array}$ \\
\hline
\end{tabular}

$\mathrm{r}=$ Multiple Correlation Coefficient; $\mathrm{a}=$ Intercept; $\mathrm{b} 1$ and b2 = Regression Coefficient;

S.E $=$ Standard Error; $\mathrm{r} 2=$ Proportion of Variance due to Regression;

$\mathrm{VIF}=$ Variance Inflation Factor; $* * *=\mathrm{P}<0.001 ; \mathrm{n} . \mathrm{s}=>0.05$

\subsection{Metal interactions}

By using correlation analysis, metal interactions of different metals ( $\mu g g-1)$ in wet body weight for wild Colisa lalia were tested. Cobalt showed highly significant positive correlation $(\mathrm{p}<0.001)$ with $\mathrm{Cd}, \mathrm{Fe}$ and non-significant correlation with Ni (Table-6).

Table 6: Inter-Elemental Regression Parameters of Cobalt (Mgg-1) Versus Different Metals (Mgg-1) in Wet Body Weight for Wild Colisa Lalia $(\mathrm{N}=23)$

\begin{tabular}{lllll}
\hline Element & $\mathrm{r}$ & $\mathrm{a}$ & $\mathrm{b}$ & $\mathrm{S} . \mathrm{E}(\mathrm{b})$ \\
\hline $\mathrm{Cd}$ & $0.771^{* * *}$ & 0.141 & 0.013 & 0.002 \\
$\mathrm{Fe}$ & $0.738^{* * *}$ & -5.095 & 3.667 & 0.729 \\
$\mathrm{Mn}$ & $0.604^{* *}$ & 6.396 & 0.174 & 0.050 \\
$\mathrm{Ni}$ & $0.065^{\text {ns }}$ & 0.598 & -0.008 & 0.002 \\
\hline $\mathrm{a}=$ Intercept; $\mathrm{b}=$ Slope; S.E $=$ Standard Error; & r = Correlation Coefficient; \\
$* * *=\mathrm{P}<0.001 ;$ & & & \\
n.s. $=>0.05$ & & & &
\end{tabular}

\section{Discussion}

\subsection{Effect of Size of fish on metal concentrations}

One of the main purposes of this study was to relate heavy metal concentrations in whole fish body, its total length and weight. As these are responsible for variations, regression analysis was done to find dependence of these elements on size. Fe and Mn showed positive allometry (b>1.0). Similarly isometry of Co with weight has been observed in Wallago atto by Yousaf et al. (2012) and also in Oncorhynchus mykiss by Naeem et al. (2010).Regression analysis for metal concentration and total length showed that $\mathrm{Co}$ and $\mathrm{Fe}$ showed isometry $(\mathrm{b}=3.0)$ while $\mathrm{Mn}$ and Ni showed positive allometry (b>3.0). Isometry of $\mathrm{Fe}$ and $\mathrm{Co}$ with length has also been observed in Oncorhynchus mykiss by Naeem et al. (2010). Effect of Condition Factor of the Fish on metal concentrations In this study, Colisa lalia showed no relation with condition factor because of different food requirement. So, morphometric condition of fish is often used to give estimation of supply of diet, important components of diet, energy demand. As it has been suggested that for wild fish the growth depends on condition of entry of important dietary components responsible for providing energy and intake of pollutants in small quantity which indicate health (Sherwood et al., 2000).

\subsection{Multiple regression analysis (MRA)}

For calculating regression analysis between two factors like length and weight, insignificant relationship was found $(\mathrm{p}>0.05)$ for $\mathrm{Cd}$, Co. $\mathrm{Fe}, \mathrm{Mn}$ but significantly high relationship was found $(\mathrm{P}<0.001)$ only for Ni values in observed fish.

\subsection{Inter-elemental regression}

Various results have been observed in the present study regarding inter-elemental regression, there were equal cases of significance and non-significant relations among metals. Regression between different metals has value for comparing when related research is done (Burger \& Gochfeld, 2010).

\subsection{Maximum permitted limits of metals in fish}

The concentration of elements found in observed fish were below the permitted levels set by different international organizations (Table-8). But the concentrations of $\mathrm{Co}$ in all samples except one was more than permitted limit established by IAEA-407,2003 (Wyse et al. 2003).Similarly the concentration of Ni in eight samples was more than permitted level established by IAEA-407,2003 (Wyse et al. 2003).

\subsection{Concluding remarks}

Results obtained in this study can provide reliable estimates of the whole body elemental concentrations in various sizes of Colisa lalia within the range used. It is insectivorous fish and feeds on mosquito larvae so it is beneficial as antimalarial and antidengue measure. Elevated concentration of Cobalt and $\mathrm{Ni}$ can be a threat to not only to freshwater biota but also human being. As high Nickel concentration in water cause allergic problems in human skin (which are sensitive to it) and high concentrations of cobalt may increase mortality rate of observed fish which feed on larvae of mosquito. However, more research work is required at larger scale to understand contamination level of water and biota.

Table 8: Permissible limits $(\mu \mathrm{g} / \mathrm{G})$ For Metals Recommended by Various Organizations.

\begin{tabular}{llllll}
\hline Source & $\mathrm{Cd}$ & $\mathrm{Co}$ & $\mathrm{Fe}$ & $\mathrm{Mn}$ & $\mathrm{Ni}$ \\
\hline FAO (1983) & .05 & - & - & - & - \\
UNEP (1985) & 0.3 & - & - & - & - \\
FEPA (1991) & 0.05 & - & - & 5.0 & - \\
TFC (2002) & 0.05 & - & - & - & - \\
IAEA-407 & 0.18 & 0.10 & 146 & 3.52 & 0.60 \\
Wyse et al. 2003 & 0.05 & - & - & - & - \\
EC (2005) & & & & & \\
\hline
\end{tabular}

\section{References}

[1] Abu-Darwish, MS, Al-Fraihat, AH, SYA Al-Dalain, Afifi, FU \& JA Al-Tabbal (2011). Determination of essential oils and heavy metals accumulation in Salvia officinalis cultivated in three intraraw spacing in ash-shoubak, Jordan. Int J Agric Biol, 13: 981-985.

[2] Agah, H, Leermakers, M, Elskens, M, Fatemi, SMR. \& Baeyens, W (2009). Accumulation of trace metals in the muscles and liver tissues of five fish species from the Persian Gulf. Environ. Monit. Assess. 157: 499- 514. http://dx.doi.org/10.1007/s10661-008-0551-8.

[3] Ashraf, W (2005). Accumulation of heavy metals in kidney and heart tissues of Epinephelus microdon fish from the Arabian Gulf. Environ. Monitor. Assess, 101: 311-316. http://dx.doi.org/10.1007/s10661-005-0298-4.

[4] Canli, M, \& Atli, G (2003). The relationships between heavy metal $(\mathrm{Cd}, \mathrm{Cr}, \mathrm{Cu}, \mathrm{Fe}, \mathrm{Pb}, \mathrm{Zn})$ levels and the size of six Mediterranean fish species, Environ. Pollut. 121:129-136. http://dx.doi.org/10.1016/S0269-7491(02)00194-X.

[5] Cid, BP, Boia, C, Pombo, L \& Rebelo, E (2001). Determination of trace metals in fish species of the Ria de Aveiro (Portugal) by elec- 
tro thermal atomic absorption spectrometry. Fd. Chem., 75: 93 100. http://dx.doi.org/10.1016/S0308-8146(01)00184-4

[6] Falandysz, J, (1994). Metal content in the muscular tissue of turbot Psetta maxima from the Gdansk Bay, Bromat. Chem Toksykol, 27: 37-39.

[7] FAO (1983). Compilation of legal limits for hazardous substances in fish and fishery products. FAO Fishery Circular, No. (464): 5 100

[8] FAO (1995). Quality and Changes in Fresh Fish, FAO Fisheries Tech. Pap. 348, Iss. No. 429 - 9345.

[9] FEPA (Food and Environment Protection Act) (1991). Guide lines and standard for environmental pollution control in Nigeria. Federal government protection agency, Lagos.

[10] Kousar, S \& Javed, J (2014). Heavy metals toxicity and bioaccumulation patterns in the body

[11] Organs of four fresh water fish species. Pak Vet J, 34(2): 161-164.

[12] Kostecki, M (2000). Heavy metals in flesh and liver of some fish species in Dzierżono Duże dam-reservoir (Upper Silesia), Archives of Environmental Protection, 26(4): 109-25.

[13] Kroupa, M \& Hartvich, P (1990). Concentrations of some heavy metals in fish. Zivocisna Vyroba, 35: 937-943.

[14] Langston, WJ (1990). Toxic effects of metals and the incidence of marine ecosystems: In: Heavy metals in the marine environment. R.W. Furness, P.S. Rainbow, (Eds.), CRC Press, New York.

[15] Lavilla, I, Vilas, P \& Bendicho, C (2008). Fast determination of arsenic, selenium, nickel and vanadium in fish and shellfish by electrothermal atomic absorption spectrometry following ultrasound-assisted extraction. Fd. Chem., 106: 403-409. http://dx.doi.org/10.1016/j.foodchem.2007.05.072.

[16] Linkov, F, Hussein, IS, Taloli, E, Laporte, R. and Al-Oufi, H. S. 2009. The supercourse of Fisheries:Importance of sharing educational materials and implications for cancer and chronic disease research.Nutrition and health.2: 31-40. http://dx.doi.org/10.1177/026010600902000104.

[17] Luczynska, J \& Tonska, E (2006). The effect of fish size on the content of Zinc, Iron, Copper and Manganase in the muscles of perch (Perca fluvitilis L.) and pike (Esox lucisus L.). Arch.Pol. Fish. 14: 5-13

[18] Malik, N, Biswas, AK, Qureshi, TA, Borana, K \& Virha, R (2010). Bioaccumulation of heavy metals in fish tissues of a freshwater lake of Bhopal. Environ. Monit. Assess. 160: 267-267. http://dx.doi.org/10.1007/s10661-008-0693-8.

[19] Nnaji, JC, Okoye, FC, Madu, CT, Omeje,VO, Wonah, C, Nuhu, M \& Isah, J (2009). Optimum temperature and transportation density for tilapia (Oreochromis niloticus) broodstock in the semi-arid zone of Nigeria. J.aqual. Sci., 24:21-24.

[20] Naeem, M, Salam, A, Tahir, SS. \& Rauf, N (2010). Assessment of the essential element and toxic heavy metals in hatchery reared $O n-$ corhynchus mykiss. Int. J Agric Biol, 12: 935-938.

[21] Newman, MC \& Doubet, DK (1989). Size dependence of mercury (II) accumulation kinetics in the mosquito fish, Gambusia affinis (Baired and Girard). Arch Environ Contam Toxicol. 18:819-825. http://dx.doi.org/10.1007/BF01160295.

[22] Ozuni, E, Dhaskali, L, Abeshi, J, Zogaj, M, Haziri, I, Beqiraj, D \& Latifi, F (2010). Heavy metals in fish for public consumption and consumer protection.Natura montenegrina, Podgorica. 9(3): 848851.

[23] Phillips, DJH, (1980). Quantitative Aquatic biological indicators. Applied Science Publishers, London, pp: 488-493.

[24] Papagiannis, I, Kagalou, I, Leonardos, J, Petridis, D \& Kalfakakou, V (2004). Copper and zinc in four freshwater fish species from Lake Pamvotis (Greece). Environ. Int., 30: 357-362. http://dx.doi.org/10.1016/i.envint.2003.08.002.

[25] Promya, J \& Chitmanat, C (2011). The effects of Spirulina platensis and Cladophora algae on the growth performance, meat quality and immunity stimulating capacity of the African sharptooth catfish (Clarias gariepinus). Int J Agric Biol, 13: 77-82.

[26] Rafflenbeul, W (2001). Fish for a healthy heart. European Journal of Fat Science and Technology, 103: 315-317. http://dx.doi.org/10.1002/1438-9312(200105)103:5<315::AIDEJLT315>3.0.CO;2-H

[27] Rashed, MN (2001). Monitoring of environmental heavy metals in fish from Nasser Lake. Environ. Int., 27: 27-33. http://dx.doi.org/10.1016/S0160-4120(01)00050-2.

[28] Sekabira, K, Origa, HO, Basamba, TA, Mutumba, G \& Kakudidi, E (2010). Assessment of heavy metal pollution in the urban stream sediments and its tributaries. Int J Environ Sci Technol, 7: 435-446. http://dx.doi.org/10.1007/BF03326153.

[29] Sherwood, GD, Rasmussen, DJ \& Rowan, DJ (2000). Bioenergetic costs of heavy metal exposure in yellow perch (Perca flavescens):
In situ estimates with a radiotracer (137Cs) technique. Can. J. Fish. Aquat. Sci., (57): 441-50. http://dx.doi.org/10.1139/f99-268.

[30] Sialkot Water Supply, Sewerage and Drainage Strategy and Action Plan (2010). Punjab Cities Improvement Investment Program. Government of Punjab. TA 7321 - PAK.

[31] Sobha, K, Poornima, A, Harini, P \& Veeraiah, K (2007). A study on biochemical changes in the fresh water fish, Catla catla (Hamilton) exposed to the heavey metal toxidant cadmium chloride Kathmandu university journal of science, engineering and technology. Vol.i no iv.

[32] Taweel, A, Shuhaimi-Othman, M \& Ahmad, AK (2013). Assessment of heavy metals in tilapia fish (Oreochromis niloticus) from the Langat River and Engineering Lake in Bangi, Malaysia, and evaluation of the health risk from tilapia consumption. Ecotoxicol Environ Saf. $2013 \quad$ Jul; $\quad 93: 45-51$. http://dx.doi.org/10.1016/j.ecoenv.2013.03.031.

[33] TFC, Turkish Food Codes (2002). Official Gazette, 23 September 2002, No. 24885

[34] UNEP (United Nation Environment Programme) (1985). Reference Methods for Marine Pollution Studies, Determination of total $\mathrm{Hg}$ in marine sediments and suspended solids by cold vapour AAS, 26

[35] Venugopal, T, Giridharan, L \& Jayaprakash, M (2009). Characterization and risk assessment studies of bed sediments of River AdyarAn application of speciation study. Int J Environ Res. 3: 581-598.

[36] Waqar KI, Ahmad, R, Kausar, T, Tabassum \& Muhammad, A (2013).Use of bioremediated sewage effluent for fish survival. Int $J$ Agric Biol, 15: 988992.

[37] Wyse, EJ, Azemard, S \& Mora, SJ (2003). Report on the Worldwide Intercomparison Exercise for the Determination of Trace Elements and Methylmercury in Fish Homogenate IAEA-407, IAEA/AL/144 (IAEA/MEL/72), IAEA, Monaco.

[38] Yap, CK, Jusoh, A, Leong, WJ, Karami, A, Ong, GH (2015). Potential human health risk assessment of heavy metals via the consumption of tilapia Oreochromis mossambicus collected from contaminated and uncontaminated ponds. Environ Monit Assess. 187(9):584. http://dx.doi.org/10.1007/s10661-015-4812-z.

[39] Yousaf, M, Salam, A, Naeem, M \& Khokhar, MY (2012). Effect of body size on elemental concentration in wild Wallago attu (Bloch and Schneider) from southern Punjab, Pakistan African J Biotechnol Vol. 11(7): pp. 1764-1767, 24.

[40] Zhang, L \& Wang, WX (2007). Size dependence of the potential for metal biomagnification in early life stages of marine fish. Environmental toxicology and chemistry.26 (4): 787-794. http://dx.doi.org/10.1897/06-348R.1.

[41] Zhu, F, Qu, L, Fan, W, Wang, A, Hao, H, Li, X \& Yao, S (2015). Study on heavy metal levels and its health risk assessment in some edible fishes from Nansi Lake, China. Environ Monit Assess. 2015 Apr; 187(4):161. http://dx.doi.org/10.1007/s10661-015-4355-3. 